\title{
Why were developing countries trapped in electricity shortage and possible policy solutions
}

\author{
Ziyan Zhang \\ Beijing No.4 High School, China
}

\begin{abstract}
.
As a high school student, I conducted a research project in some cities of Pakistan and Bangladesh. The goal of this research is to explore the relationship between the electricity generation level and economic development in developing countries and to figure out what are the factors result in power shortage and insufficient infrastructure for residents. During the two weeks in 2018, using the methods of field research and deep interview with both the locals and the CEO of some power plants, details about the hard life of local citizens and the aspects that extremely need improvement are recorded. According to an analysis of the electricity shortage problems and the causes in the inefficient national economic policies and company operating in a bureaucratic manner, there are some policies and suggestions aimed at addressing the problems: first, since the maintenance of a stable environment is the precondition for the development, the state should spend more efforts in restoring public order; second, the management operation of an electricity power company shall follow the principles of Efficiency First; third, on the premise of respecting the local traditional culture, the labor participation rate shall be properly enhanced; more importantly, the employment rate should improve by increasing the construction of local infrastructures. As a foreigner, in less than one month of investigation, I cannot fully understand all the problems and the more complex reasons. However, I hope these suggestions may become the reference to policymakers who are both capable and willing to solve related issues.
\end{abstract}

Keywords: Bangladesh, electric power generation, electricity shortage, Pakistan

\section{Introduction \& motivation}

Development is the basic human right. According to the Human Development Index, the infrastructure such as electric power has a significant influence on the living standard of the residents in a country. In the operation of the modern industrial economy, electricity is the main power source of economic activity. For people's life, electric is also an essential resource for daily interaction. More importantly, economic growth is highly related to the level of its annual electricity generation (Zhang, 2009).

With reference to the relationship between the GDP and Generating Capacity in the world , Table-1 clearly shows that when the generating capacity of a country is in the higher level, 
it has a higher GDP, and vise verse. For example, the annual Generating Capacity per capita in Canada in $2013 \$ 52,000$, ranked the fourth in the world, higher than most countries that belong to the bottom-left corner.

Why are so many countries in the world having problems with inadequate electricity generation capacity? What are the factors that have left the residents in these countries with insufficient electricity power, and therefore made them unable to enjoy economic development? After my investigation and analysis, I found that the tough economic development environment and the problems embedded in the management system of those electric power companies are the critical factors leading to its under-development., According to these findings, I have proposed some policies and suggestions in my thesis.

Figure 1. Diagram of GDP and Generating Capacity

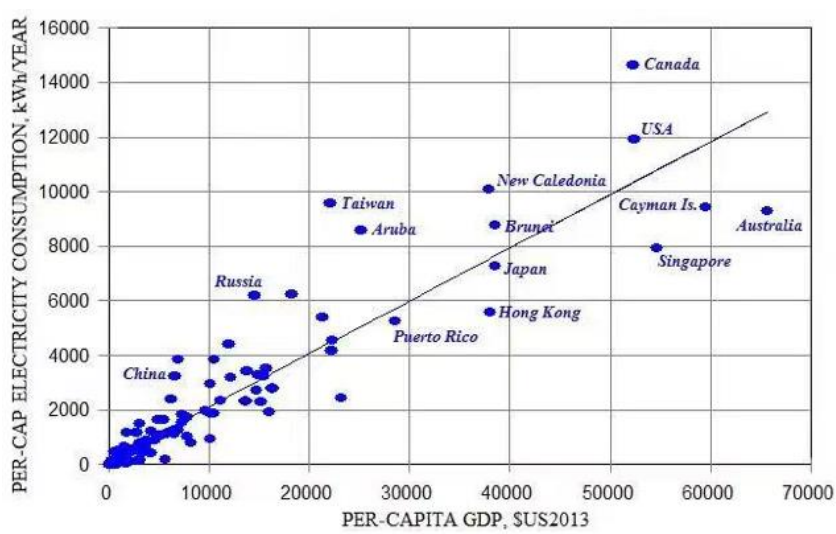

Source: (TNR 10pt. italics)

\section{Literature review}

From the relationship between supply and demand, there are two major problems resulting in the difficulty that the residents of developing countries fail in the electric consumption. One is the shortage of electric production and the other is their affordability of demand. On the demand side, the consumption of electricity is constrained by family income. In developing countries, the average income of families is seriously inadequate, which can hardly support the electric consumption.

Figure 2. Map of Pakistan, India, and Bangladesh 


\section{1 - 23 JUNE 2019 \\ VIENNA, AUSTRIA}

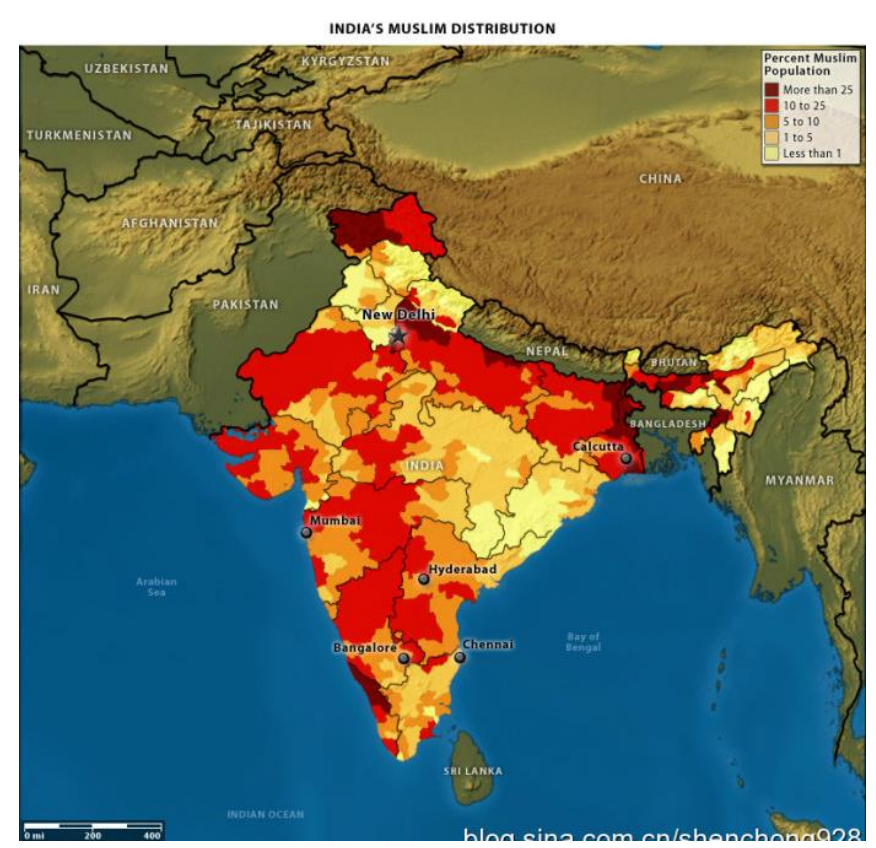

Some serious social issues related to the institutions are also important factors leading to the low income of the families in those countries:

Firstly, women's labor participation rights are highly limited. If women were liberated from families to obtain compensation through labor work, the income of families shall be substantially increased. According to the literature, empowering women labor force can significantly improve the well-being of their families (Wang \& Liu, 2002).

Secondly, social stability plays a significant role in a country. The lack of security to ensure personal property rights and life safety will suppress the industrial and commercial vitality, followed by depressed economic activities and growth. David A. Leblang found in his research that (1) Economies of nations that protect property rights grow more rapidly than those that fail; and (2) The nature of a political regime influences economic growth indirectly through its commitment to property rights (Leblang, 1996). There is one classical example in the book "Why Nations Fail" by Acemoglu and Robinson that the small city Nogales is divided into two by the US and Mexico. The people in the North Nogales, where the rule of law was firmly established, have led a high standard life in a vigorous economic environment. While the people in South Nogales in Mexico led a difficult living in a society full of drug and gun crime and a terrible economic environment (Robinson \& Acemoglu, 2012).

Table 1. Electricity Price of Different Countries in the World 


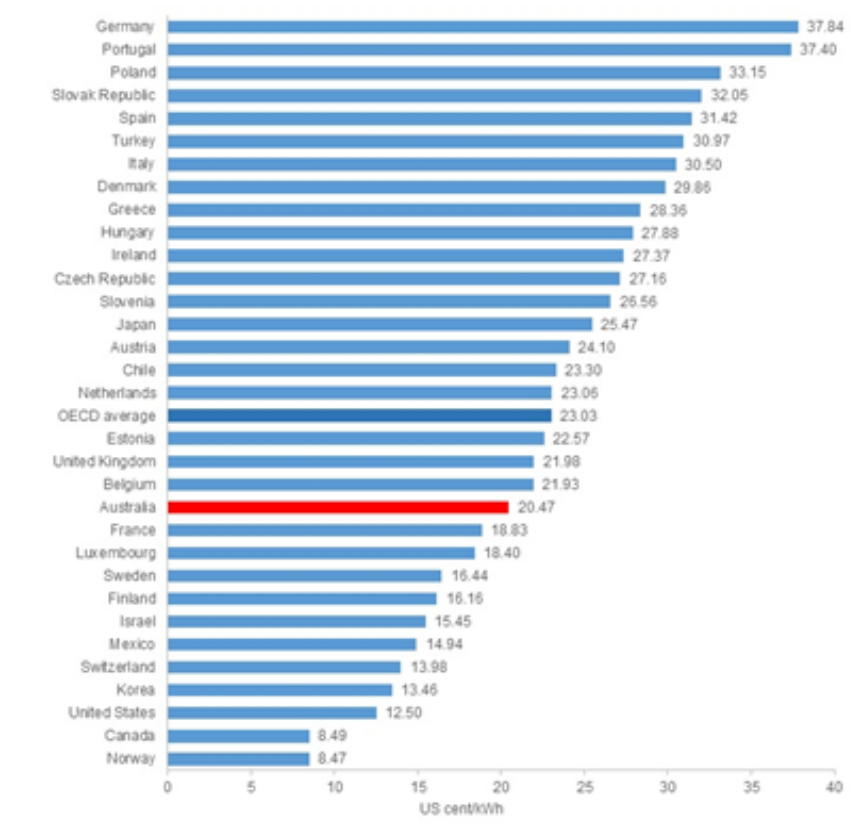

\subsection{Overview of Electric Generation and Consumption in Pakistan and Bangladesh}

Both Pakistan and Bangladesh, known as "State of Muslim", are developing countries in the South Asian Sub-Continent. Geographically, these two countries are located on the northwest and northeast sides of India, respectively. Before India became independent in 1947, these two countries were parts of British India. In the partition of India on August 14, 1947, Pakistan declared independence and Bangladesh belonged to Pakistan, called East Pakistan. In 1971, Bangladesh was separated from Pakistan and became independent.

Both Pakistan and Bangladesh are developing countries measured by GDP per capita ranking in the world and population size, and belong to underdeveloped capitalist market economies. It is known from the newest report in the international summit forum on "The Belt and The Road" that at present, the problem which affects the people's livelihood and social development in Pakistan is the electric shortage. Although, in general, the electricity generation capacity of these two countries is on the rise. However, there is still a long way to go to satisfy the need of all the people.

\section{Interview content and data analysis}

My interview began with Nazir Ahmed's family. He, his old father and a five-year-old little son sat in front of me silently. The way they dress suggests that they belong to the population of lower-middle-class in the part of Pakistan.

As the only labor force in the family, Nazir Ahmed is 33 years old this year. In order to shoulder the burden of his whole family, he had to quit school for work although he only took education for ten years. Helped by his younger sister, he is now managing a laundry. There are 
seven family members, including his two wives, three children, and his old father. His family earns 35,000 rupees every month (appropriately \$248) and can save 15,000-20,000 rupee every month after all the expenses (appropriately \$106-144), which will be saved for his children's education, marriage, diseases and pension for the aged and other unforeseen possibilities. As to electric appliance, all the belongings of Ahmed's family is a TV set, a washing machine, and a refrigerator.

During the interview, when I particularly asked his old father's opinion on current life, it is surprised to me that compared to life changed by electric, he misses the old days. They cannot bear higher price although now electric devices can enhance their living standard. The electric appliance in the family does not materially improve their family life. Compared to the past, he thinks that their life becomes harder. Ahmed hopes that his children will become doctors with high salary.

Compared to Nazir Ahmed's family, the second family I interviewed belongs to the lowest class. Amanat is a teacher in the local rural school. There are 16 people in his family, including three brothers, their wives, children, and their sick old mother.

His family has an independent yard. However, due to their poverty, they can just build three simple bungalows. They cook by burning tree branches and take drinking water from an old well in their yard. The sanitary condition and infrastructure are also very poor. The only electric appliance in the family is a used 12' black and white TV set which shall be more than 20 years old.

Amanat is the only labor force who has a fixed job and stable income. His two brothers do not have jobs that bring stable income and just do some temporary work to earn slender income; the females in the family do not work and they do some chore work in the family yard. Their sick old mother just lies in the yard to wait for death as the family does not have disposal money to cure her disease (which makes the profession of the doctor as a precious job locally and a dream for many people).

The income of Amanat's family is approximately 15,000 rupee (appropriately \$106). The electric consumption every month is 300-500 kilowatt-hours, accounting for one-fifth of the family's gross income per month.

They are not very satisfied with the electric price, they think that they do not have the affordability although the electric system in the country becomes more developed. As they cannot pay for their children's education, they feel pessimistic about their children's future.

They also have certain expectations and the requirement for their government, and hope the government to provide:

1. More job opportunities for the local residents;

2. Clean drinking water; 


\section{1 - 23 JUNE 2019 \\ VIENNA, AUSTRIA}

3. Cheap natural gas for cooking meals (and now, they have to do it by burning tree branches).

Through deep interviews and observations, these families have some common features:

1. There are about ten people in a family, but there is only one adult male who has a stable job with fixed income. The monthly income of these two families is e lower than $\$ 250$ and the slender income can only meet their basic living needs. The poverty line set by the United Nations is $\$ 2$ per capita as of daily living expense. Therefore, the poverty line is $\$ 600$ for a family of ten people. It can be seen that the income of these two families is much below the poverty line.

2. The electric charge in Pakistan is 10 Rupee, approximately equal to $\$ 0.09$. It can be seen from the graph below that compared to other countries and regions in the world, the electricity price in Pakistan is at a lower level. However, local people think that the price per kilowatt-hour is too expensive, even if the government provides subsidies. Every day, they will only turn on the TV and watch the news for less than an hour and in ordinary time, they will not use electricity. Therefore, we can conclude that insufficient electric consumption and low demand are caused essentially by insufficient family income.

3. Women's social status is generally low, they do not have job opportunities. What they do every day is to raise children or become pregnant to get prepared for giving birth to another child.

4. Locally, there are many people without a job and stable income, due to insufficient job opportunities locally.

5. As to the expectation for their descendants, these families have no ways of undertaking the investment for their children's education and cultivation because of low income. Although they expect for a better future for the male descendants, it seems impossible to be realized and, in the future, they may fall into a vicious cycle of poverty.

After interviewing the end users of electric, let's listen to how the electric producers evaluate the industry of their own work.

Guddu Power Plant is located in the middle of Pakistan, in the junction of the three provinces of Sindh, Punjab, and Baluchistan. Mr. Mohammad Aoub Ansari whom I interviewed first is the CEO of this plant. The electric which this plant generates will be transmitted to the national power grid and be distributed to the consumer. This plant provides $8 \%$ of the electric for the country and approximately 16 million people benefit from Guddu Power Plant. This plant adopts self-financing mode and has no subsidy from the government.

The power companies in Pakistan are operated basically by self-finance and the government provides little subsidy because of the limitation of the national finance resources. Hence, the 


\section{$21-23$ JUNE 2019 \\ VIENNA, AUSTRIA}

operation efficiency of the company is of great importance to its viability. From the perspective of business administration system, Guddu Power Plant has the following incentive systems which ensure high efficiency of operation:

1. The plant is never in arrears of wages. If someone shirks, he will be inquired and warned and finally, he will be expelled through a legal procedure.

2. There are more than 2,000 employees in the plant. Compared to other ordinary people in lower classes, they enjoy higher wages and every year, the plant will pay bonus according to the annual profit (one or two times a year).

Figure 3. Map of Guddu Power Plant, Pakistan

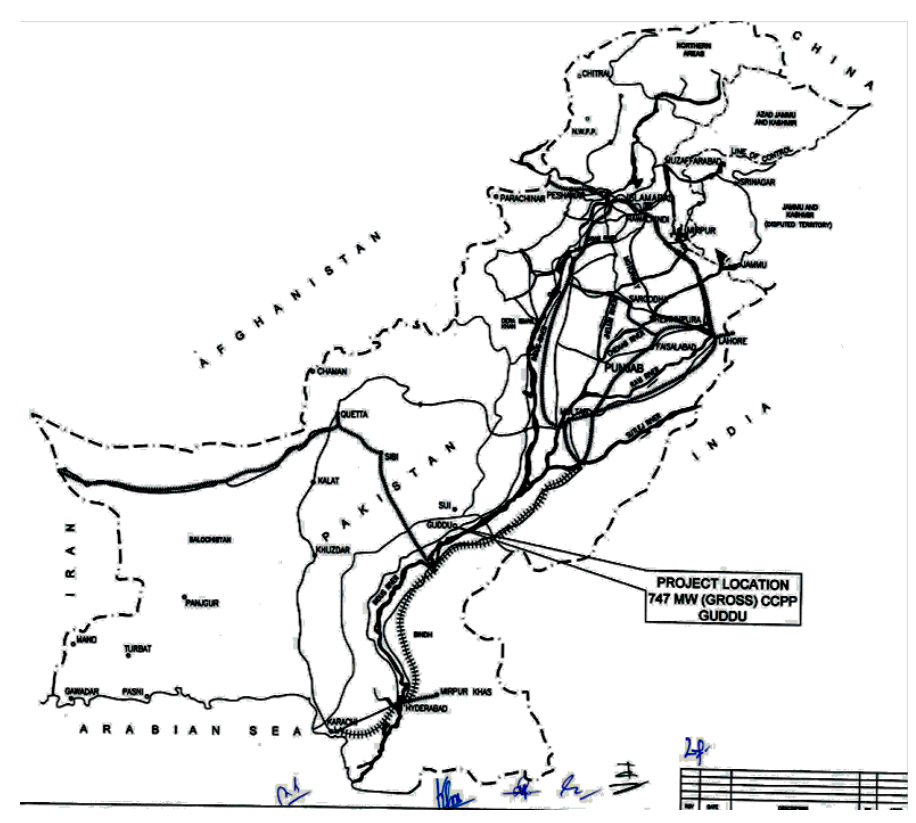

We can see from Table 2 below that the annual generating capacity of this plant is trending up.

Table 2. The title of this table

\begin{tabular}{|c|c|}
\hline Year & Gross Generation (M.kWh) \\
\hline $2013-2014$ & 4,527 \\
\hline $2014-2015$ & 5,715 \\
\hline $2015-2016$ & 6,030 \\
\hline $2016-2017$ & 8,079 \\
\hline
\end{tabular}




\section{1 - 23 JUNE $2019 \quad$ VIENNA, AUSTRIA}

\begin{tabular}{|c|c|}
\hline $2017-2018$ & 8,943 \\
\hline
\end{tabular}

Data sources: interview with CEO of Guddu Power Plant and data collection

The second person I interview with is Muhammad Imran, the General Manager of Pakistan National Power Generation Group. Different from the former CEO who was appointed to the senior management post when he nearly reached the retirement age of 60 years old, energetic Imran is a typical young professional manager. He introduced to me: $98 \%$ of the all the electricity in the country comes from the public power plants of the national power generation group including Guddu Power Plant. The total capacity of the group is $24,000 \mathrm{MW}$ and the generating capacity is $15,000-17,500 \mathrm{MW}$. The electric consumption per capita in the country is approximately $0.085 \sim 0.1 \mathrm{KWh}$ per person. Surely, Pakistan is still a backward country in electricity.

As Pakistan has limited financial resources, the power plants of the group were built by taking the loans from other countries and the annual return on the investment is $14 \%-16 \%$. The efforts and support from the government for these years have improved the power situation to some extent. However, compared to the $1 \sim 10 \mathrm{KW} / \mathrm{h}$ of electric consumption per capita in the developed countries, there is a long way to go for Pakistan to reach an ideal level of electric generation. In order to continuously improve the electric generation capacity from backwardness, the policy assistance from the international society such as "The Belt and The Road" has played an important role. In 2017, Pakistan built ten thermal power generation units with a 600MW equivalent one after another, which has greatly eased power shortage in Pakistan. All of these ten units are the projects which China invested or funded through "The Belt and The Road".

"Of course, the country and foreign investment have provided a starting point for the development and most importantly, if we want to be on the track to the stable and sustainable development, we have to depend on the efforts of these electric companies", Imran said at the end of our talk.

Compared to Pakistan, the power plants in Bangladesh have similar situations. Barapukuria Power Plant in Bangladesh which I interviewed is located 45 kilometers from the southeast of Dinajpur, northwest of Bangladesh, approximately 20 kilometers from the northeast of the border with India. Mr. Achhher Ali, the operating manager of the power plant, received my interview.

Barapukuria Power Plant was built in two phases. In the first phase, two units of $125 \mathrm{MW}$ were put into use in 2006. At present, the units are not in a good running status that produces only 70-80MW of the rated operation level because of lack of normal maintenance and the local employees' lower operation ability. The newly-built 300MW unit in the second phase was put into use in 2016 by the Favorable Loan of ICBC (Industrial and Commercial Bank of China). 
With better maintenance and as the major operators are the Chinese engineers, the unit runs properly and can basically reach $100 \%$ of the electric generation level.

Figure 4. Map of Barapukuria Power Plant, Bangladash

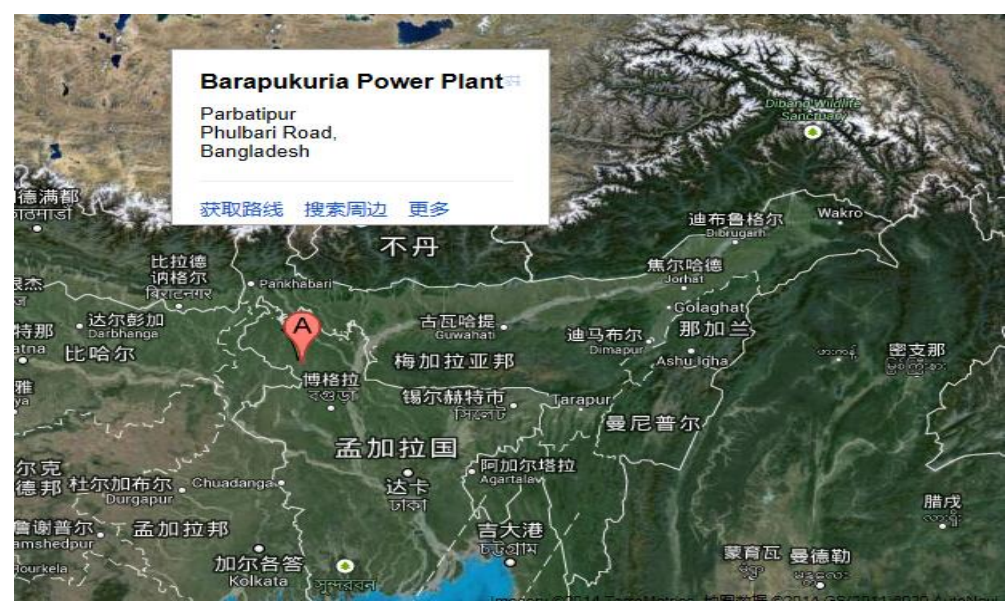

When talking about how to improve the running status of the first-phase unit, Mr. Ali looked helpless. He mentioned that as Bangladesh faced electric shortage and lacked fund, the two units in the first phase were not operated continuously for a long time and there was no time and money to stop them for maintenance. The electric generation level of the power plant is terrible and the coal consumption for electric generation reaches as high as 500-600g per kilowatt hour. The running cost is much higher than $350 \mathrm{~g}$ per kilowatt hour of the second-phase unit which is just put into use. In order to maintain the operation of the units, the government has to provide subsidy for the power plant; and on the other hand, the government has to provide subsidy to make the electric price lower than the cost to make residents better afford the high electric charges. The income of the plant employees is generally low, the experienced employees will switch to another company in other Middle East countries, such as the United Arab Emirates and Saudi Arabia to earn high wages to improve their family's life. As a result, the operating level of the units cannot match those operated by Chinese engineers in the secondphase unit.

Table 3. Comparation of Guddu and Barapucuria Power Plant

\begin{tabular}{|c|c|c|}
\hline & Guddu Power Plant of Pakistan & $\begin{array}{c}\text { Barapukuria Power Plant of } \\
\text { Bangladesh }\end{array}$ \\
\hline $\begin{array}{c}\text { Whether the company enjoys } \\
\text { subsidy from the government }\end{array}$ & None & None \\
\hline
\end{tabular}

We can see from the comparison between the two power plants in Pakistan and Bangladesh that compared to the $85-90 \%$ of the power plants in the countries with developed electric, the 


\begin{tabular}{|c|c|c|c|c|}
\hline & $\begin{array}{l}\text { Capability } \\
(\mathrm{MW})\end{array}$ & $\begin{array}{c}\text { Electric charge } \\
\$ / \mathrm{KWh}\end{array}$ & $\begin{array}{l}\text { Capability } \\
\text { (MW) }\end{array}$ & $\begin{array}{l}\text { Electric } \\
\text { charge } \\
\text { \$/KWh }\end{array}$ \\
\hline \multirow{4}{*}{$\begin{array}{l}\text { Capacity (MW) of the plant Vs price } \\
\text { per kilowatt hour (\$ per kilowatt hour) }\end{array}$} & 747 & 0.034 & \multirow{4}{*}{ (actually 400) } & \multirow{4}{*}{0.06} \\
\hline & 600 & 0.037 & & \\
\hline & 420 & $>0.052$ & & \\
\hline & 130 & $>0.052$ & & \\
\hline Number of employees in the plant & \multicolumn{2}{|c|}{$>2000$} & \multicolumn{2}{|c|}{600} \\
\hline Whether there is bonus incentives & \multicolumn{2}{|c|}{ Yes, one to two times a year } & \multicolumn{2}{|c|}{ None } \\
\hline $\begin{array}{l}\text { Whether there is a system } \\
\text { of punishment }\end{array}$ & \multicolumn{2}{|c|}{ Yes } & \multicolumn{2}{|c|}{ None } \\
\hline
\end{tabular}

Running Availability in appropriately $70 \%$ of the power plants in Pakistan and Bangladesh is at a lower level although the power plants in Pakistan is running in a better trend. It is very complex of the reason why the residents in these two countries face electric load shedding with such a weak producing capability, including the national problem of the unstable regime, the social problem of the tight security, the economic problem of the residents' poverty and the enterprise system problem of the terrible management efficiency.

1. The stability of the government shall ensure the continuity of the energy policy:

Pakistan and Bangladesh are the countries with unstable central government leading to a bad continuity of policy and the coming government usually failed to follow the policy of the former.

For example, the former Pakistan President Sharif proposed a slogan to solve the electric issues when he came into power. During the time when he was at the helm of the state, the electric load shedding was greatly improved. Moreover, the foreign currency exchange rate had been maintained in a stable way for nearly four years. However, in April 2018, the opposition party threw him out on unsupported corruption charges. Consequently, within nearly half a year of election time from April to September 2018, the entire country was falling into an anarchy situation. Whereas, the newly voted prime minister, who had earned as a national hero in his cricket player career, showed lack governing experience in economic development nor power policy. In the following three to four months when the new government took into power, the national economy slides down seriously and the national foreign currency reserve fell to $\$ 7.9$ billion only. Even 
worse, some unimaginable event occurred that the contract of national power fuel procurement was not even renewed in the election time interval.

The development of electric infrastructure depends on huge investment and a relatively higher amount of funds. The investment return, that may not be covered in a short time, shall be realized in the long term of economic development with continuous increasing power demand. To some extent, the electoral politics interrupt the continuity of policy, leading to the unstable financial support, the inconsistent long-term plans and the slow development of electric power department.

2. The overstaffing business model is management abuse at the enterprise level:

An interesting phenomenon was found in my investigation that no matter in Pakistan or in Bangladesh, some senior management showed lack willing to improve the electric power supply. One of the reason is that there is an unwritten rule on the election of a senior manager in these two countries: the government will promote an official to a higher position 1 or 2 years before he retires on the purpose of letting him enjoy better treatment after his retirement. However, it is consequent that the efficiency of the whole administrative departments of public services is much lower. The bureaucratism is trying to seek no accomplishment but faults free and work stably until they retire and enjoy an easy life. Surely, they have no willing to bear the risk of improving operation by policy reform and innovation.

3. The high financial investment has to be put to maintain downhill security status.

Take Pakistan as an example. The hotel I stayed on the first day in Karachi is confined watchfully and the whole hotel is protected with high steel bars. At the site in Guddu Power Plant, from the time when my flight landed, Tens of soldiers escorted the car of my father and me, guns in their hands. One cruiser cleaning the way in front, and another covering the retreat. No matter what time or where we went, we were protected by the policemen. From the view of economic development, social safety and stability will directly affect personal safety and property right. If that right is not guaranteed, the citizen's motivation to take part in economic activities must be discouraged and let alone the economic development.

\section{POLICY SUGGESTIONS}

As a senior student and a foreigner, in less than one month of investigation, obviously, I cannot fully understand, as the reformers in these two countries, about all the problems and the more complex reasons behind them. Hence, I just want to propose some suggestions in a selfobservation and understanding way. I hope these suggestions may become the reference to those talents more capable who is willing to solve related issues. 
1. The maintenance of a long and stable political environment is the precondition for the development. For a developing country, an effective government is the most attractive factor to foreign investment to create opportunities for the country's economic development. And the most important aspect of attracting foreign investment is the highly deterministic economic development environment which must not be affected by the change of policy caused by the alternation of government.

2. The operation of a power enterprise shall follow the principle of Efficiency First. The organization of enterprise shall be reconstructed, a reasonable incentive system shall be established and the employees shall be encouraged to play their role. The aforesaid Human Resource system shall be changed gradually that an official is promoted to a higher position when he is nearly retired, who has no passion to lead an enterprise to a bright future.

3. On the premise of considering the local traditional culture, the labor force shall be properly liberated. Especially, the women shall be guaranteed to have more freedom to take part in the social job as a man. The government shall put more resource into education for infants or female. Women's burden of a family shall be reduced so that they can have jobs to increase their family's income level.

4. The employment rate shall be enhanced by strengthening the construction of local infrastructures such as railway, highway, house building, public facility, and factory. Funds may be raised to build roads and bridges, set up toll gates and the benefit is returned according to the percentage of investment. If the government lacks fund, it may be a practical way to apply for loans from banks or foreign financial institutions. The foreign concessional loans and the policy assistance like "The Belt, The Road" is of great importance for such countries as Pakistan and Bangladesh who are in the financial strains. Under the condition that sufficient job opportunities are created, population movement will be more frequent and the labor force will move to the regions with more job opportunities to obtain the higher reward (Zhu, 2001). As to the income in the whole society, if there is a better economic development environment, the job opportunities will be stimulated and the bonus of potential labor force will be released (Borjas et al., 1991).

\section{Feelings}

Before my visit, I thought it is quite normal to live in a stable social environment and receive a better education. However, for the people in the developing countries who struggle just to fill up the stomach and drink clean water, it may be a target for several generations to realize. In our daily life, we are accustomed to studying in the day with over lights or leave the room with the light on. We never think that the electric capacity that we waste every day is more valuable for the people in the poor areas, such as in Pakistan and Bangladesh to use per capita for three days. This great contrast is the reason to impel me flying from China to these two countries to 


\section{SOCIAL SCIENCE, HUMANITIES \& EDUCATION}

21 - 23 JUNE 2019

VIENNA, AUSTRIA

make this research. I hope that I can understand deeply the system issue behind poverty and underdevelopment, and someday in the future, I can take part in the work of solving poverty and backwardness.

\section{References}

[1] Borjas, G. J., Freeman, R. B., and Katz, L. F. (1991) “ On the Labor Market Effects of Immigration and Trade," the National Bureau of Economic Research, pp 23-25

[2] Leblang, D. (1996) "Property Rights, Democracy and Economic Growth," UNIVERSITY OF NORTH TEXAS, pp.22-26, [Online]. Available: https://doi.org/10.1177/106591299604900102

[3] Robinson, J., \& Acemoglu, R. (2012). Why nations fail. Crown Publishing Group.

[4] Wang, D. and Liu, M. (2002) "Women's participation in agricultural development and its role,” Working Paper Series No.20, pp.10-15

[5] Zhang, L. (2009), "Analyze the relationship between electricity consumption and economic growth," Economy Daily News [Online]., Available: http://finance.people.com.cn/GB/9327765.html

[6] Zhu, J. (2001), "Current Chinese labor force flow pattern, employment policy, and economic development," Chinese Population Science, pp.12-14 